\title{
Globalization, Security, Paradox: Towards a Refugee Biopolitics
}

\author{
Benjamin Muller
}

\begin{abstract}
How can we think, imagine, and make authoritative claims about contemporary refugee politics? I believe this question must precede investigations into struggles/movements advocating rights and political voice for refugees. It is important to come to terms with the changing terrain of refugee politics, in order to (re)conceptualize it and provide some idea of how/where such struggles might be fought. Focusing on the colliding commitments to globalization and security, particularly since September 11, 2001, I argue that "paradox" is a core element of refugee politics. To some extent, this has been rehearsed elsewhere, and I point to the highlights in the existing literature. I suggest that an approach sensitive to Foucault's account of governmentality and biopolitics is particularly helpful, stressing the diffuse networks of power in refugee politics among private and public actors, the increasing role of "biotechnology," and some (re)solution to the globalization - domestic security paradox, leading to what I call the "biopoliticization of refugee politics." Examined here are the politics of asylum and refugee movements in the UK. In particular, the 2002 government White Paper on immigration and asylum - Secure Borders, Safe Haven-provides an example of the changing terrain of contemporary (post-September 11) refugee (bio)politics.
\end{abstract}

\section{Résumé}

Comment pouvons-nous arriver à penser, à formuler et à adopter des positions qui fassent autorité sur les politiques du droit d'asile aujourd'hui? Je suis d'opinion que cette question doit précéder tout examen des luttes et des mouvements qui militent pour des droits et une voix au chapitre (politique) pour les réfugiés. Il est important d'être bien au fait du paysage changeant des enjeux politiques entourant le droit d'asile, afin de pouvoir le re-conceptualiser et fournir une idée de comment et où de telles luttes doivent être menées. Me concentrant sur les objectifs opposés de la globalisation et de la sécurité, tout spécialement après le 11 septembre, je propose que le "paradoxe » est un élément clé de la politique sur le droit d'asile. Dans une certaine mesure, cela a déjà été décrit ailleurs, et je souligne donc les passages importants dans la littérature existante. Je suggère qu'une approche qui serait ouverte à la thèse de Foucault sur la "gouvernementalité » et la bio-politique est particulièrement utile, soulignant le réseau de pouvoir diffuse qui existe dans les enjeux politiques autour du droit d'asile parmi les protagonistes dans les secteurs privés et publics, le rôle grandissant de la bio technologie et quelques solutions $d u$ paradoxe globalisation et sécurité intérieure, et menant à ce que j'appelle la "bio-politisation des enjeux politiques $d u$ droit d'asile ». Nous examinons ici la politique $d u$ droit d'asile et les mouvements de défense des réfugiés en Grande Bretagne. Le livre blanc de 2002 sur l'immigration et le droit d'asile, intitulé "Secure Borders, Safe Haven " ('Frontières sécurisées, havre de paix'), illustre bien les changements qui s'opèrent dans le paysage de la (bio) politique contemporaine (post 11 septembre) sur le droit d'asile.

If the nomad can be called Deterritorialized par excellence, it is precisely because there is no reterritorialization afterward as with the migrant, or upon something else as with the sedentary (the sedentary's relation with the earth is mediatized by something else, a property regime, a State apparatus).

Gilles Deleuze and Felix Guattari ${ }^{1}$ 


\section{Post-September 11 Refugee Politics: Resolving Paradox?}

$\mathrm{T}$ he events of September 11, 2001, and the aftermath with which we continue to live have touched almost all corners of political life. Almost immediately, conventional geopolitics were pulled from the dustbin of history, arguments about civilizational conflict gained unprecedented respect, and realpolitik had yet another renaissance. $^{2}$ However, the fact that this was caused by what many consider to be one of the clearest examples of globalization and/or transnationalism is often lost. Accounts of globalization sensitive to networks, simultaneities, multiple identities, fluid capital, and dramatically altered spatio-temporal relations proliferated, as these became increasingly accepted elements of daily life in late/post modernity. Yet in a puzzling reversal of fortune, the aftermath of September 11 saw states respond with conventional geopolitics, preoccupied with conventional international relations themes, such as sovereignty, borders, and bounded identities. Unfortunately for asylum seekers and forced migrants around the world, there was one exception.

Following the events of September 11, culminating most notably in the United States's creation of the Department of Homeland Security, states across the globe heightened border controls, increased passport restrictions, and embarked on an overall clampdown of movement. ${ }^{3}$ As the U.S. government's policies at the U.S.-Mexico border and the Schengen Information System (SIS) in the European Union (EU) prior to September 11 indicate, the proliferation of technologies of control and surveillance used by states to monitor and discipline movement is not unprecedented. The situation facing refugees nonetheless appears to be worsening. In the United Kingdom Tony Blair's support for George W. Bush's campaign against Iraq coupled with the government's decision to introduce restrictive quotas on the number of asylum seekers to the UK is troubling. While the asylum story in the UK can be explained partially by domestic pressure from the Conservative opposition, the events of September 11 have allowed such arguments to be couched in discourses of threats and security. ${ }^{4}$ We might ask how social movements, NGOs, and refugees themselves are coping with such an alteration in the global politics of movement. However, this paper focuses on the prior question about how we can (re)think and make authoritative claims about refugee politics. It highlights a core paradox between the "need" to increase domestic state security in light of the terrorist threats, and the continuing commitment to neoliberal globalization, and the extent to which a further "biopoliticization" of refugee politics provides a way of coping with this paradox.
Refugees find themselves at the centre of the core paradox between globalization and domestic security for a number of reasons. States committed to neoliberal globalization must sign onto its principles, one of which is the (relatively) free movement of capital, goods, services, and labour. One of the most advanced instances of this "free movement" is in the EU, where the member states signed onto Schengen have committed themselves to a kind of "borderless" union. However, states simultaneously wish to retain control over the "identity" of their nations and who is included (and excluded) vis-à-vis citizenship; and, particularly after September 11, domestic security is high on the agenda. Therefore, while it is important to allow labour mobility to serve the (perceived limitless) growth of the post-Fordist global economy, undesirables might still sneak in the back door. What is particularly puzzling since September 11 is the extent to which the terrorist attacks were in many ways exemplars of transnationalism, globalization, and postmodernity. Rather than follow the familiar model of state hierarchy, it seems terrorists have exploited the conditions of possibility in contemporary globalization organizing as transnational networks with various so-called "cells," using complex telecommunications, and, as the attacks of September 11 demonstrated, very astute about the power of the mediated image. Similarly, international human traffickers, and indeed refugees themselves, are to some extent more astute about the "new realities" of globalization, while states continue to suffer from the theme of Gulliver. ${ }^{5}$ In this sense, refugees are at the intersection of this paradox between globalization and security.

In this paper I explore this paradox between globalization and domestic security, and the impact it has on the politics of asylum. How does it alter the terrain upon which refugees are able to act? And, perhaps more importantly, to what extent does this change our ability to speak, think, and make authoritative claims about refugee politics? I begin the discussion by engaging with Nevzat Soguk's argument about the paradoxical status of refugees vis-à-vis state sovereignty, and explore this argument in light of the events of September 11 and their aftermath. This is followed by a brief discussion of Foucault's governmentality approach, focusing on the idea of biopolitics and bio-power. I then examine contemporary refugee politics in the UK in light of these theoretical offerings, highlighting how the UK has attempted to cope with the paradoxical commitments to globalization and security in the area of refugee politics. I argue that the UK White Paper entitled Secure Borders, Safe Haven exemplifies both the paradox of globalization and domestic security in contemporary refugee politics, as well as the extent to which we are witnessing a "biopoliticization" of refugee politics. Foucault's notion of biopolitics is 
helpful in uncovering the complex nature of refugee politics and how states are coping with the paradoxical commitments to globalization and domestic security. I conclude by raising a series of questions about how refugee politics have changed in the aftermath of September 11, returning to the central preoccupation with how we can (re)think and make authoritative claims - and thus act politically, whether challenging the speechlessness of refugees, or acting as rights advocates - about contemporary refugee politics. Biopolitics allows a way in, that helps to (re)conceptualize the terrain of refugee politics, highlighting states' management of the globalization-domestic security paradox, as well as providing a richer account of the diffuse networks of power among private and public actors, and the role of (mis)representations of refugee politics. For movements occupied with the rights, protection, and challenge against the political speechlessness of refugees are aided by such a topography of refugee politics that helps to uncover possible spaces and sites of struggle.

\section{Sovereignty and Refugee (Bio)politics}

As suggested, the very refugee or migrant bodies, which, while at first undermining, for instance, a state's ability to produce the claim that it is in control of its proper territories/borders, at times also become a source of re/presentation for the state(ism) whereby the state(ism) poses itself as an ontological necessity (being). I shall call this situation the 'paradox of the representable refugee'.

Nevzat Soguk ${ }^{6}$

This passage from Nevzat Soguk's account of refugees/migrants at the U.S.-Mexican border highlights the core of his argument, focusing on the paradoxical implications for practices of state sovereignty that the "refugee presences" afford. ${ }^{7}$ Soguk's "paradox of the representable refugee" is an empowering tool. It provides an account of the often complex and seemingly contradictory role refugees and migrants have in world politics, particularly in relation to practices of state sovereignty. As Giorgio Agamben astutely puts it, refugees "put the originary fiction of modern sovereignty in crisis." ${ }^{\prime 8} \mathrm{In}$ a rather similar manner, Michael Dillon argues that:

... the advent of the refugee always brings to presence this: the scandal of the human as such... as a form of making that results in a technologising of politics, seeks to save us; and in the process subject us to novel, possibly terminal, globalised terrors and dangers. ${ }^{9}$

The "scandalous" nature of the refugee fits closely with both Soguk's and Agamben's characterization of refugees. Refu- gees highlight the fragility of modern sovereignty and the "imagined communities" in which we live. This is, of course, nothing new. But what of the refugees themselves? In the next section of this paper I engage directly with the post-September 11 refugee politics, with specific reference to the situation in the UK. At issue here is the struggle to obtain rights and political voice, and how this terrain upon which this struggle is pursued, and even the conditions under which it is possible to think, imagine, and make authoritative claims about refugee politics in the post-September 11 context, characterized by a paradoxical preoccupation with globalization and domestic security. In this section, I suggest that an approach sensitive to Foucault's account of governmentality and biopolitics, in conjunction with other accounts such as Soguk's, provides a clearer picture of the changing nature of contemporary refugee (bio)politics, the focus being to open up the possibility to further (re)think and make authoritative claims about the politics of contemporary refugee movements. However, a closer examination of Soguk's argument is worthwhile before progressing.

While the kinds of arguments evoked here from the likes of Agamben, Dillon, Soguk and others are increasingly accepted among observers, the conventional story of world politics vis-à-vis the discipline of international relations fails to recognize the "scandalous" nature of the refugee, whether in terms of practices of state sovereignty, the construction/definition of "human," and articulating the "body politic." Here, the concern is with how the events of September 11 and their aftermath have altered the terrain of refugee politics, and how the conditions under which we can ask questions, think, and make claims about refugee politics have changed. The struggle for rights and political voice is critical. For Soguk, the voicelessness of the refugee is unquestionable. However, rather than linking this to the disadvantaged predicament of the refugee, or the failure to have the proper political subjectivity of state citizenship, Soguk argues that "refugee discourse" is responsible for this "speechless" condition. ${ }^{10}$ Questions of representation are critical, and the post-September 11 context is no different. The discourse has shifted, from one of humanitarianism, where questions of hospitality or cruelty may have entered in, or more identity based distinctions between the unknown alien and the familiar citizen; refugee politics has been drawn into a discourse of security and threat. As Soguk argues, "the privileging of the citizen/nation/state ensemble as the hierarchical imperative of life activities is not unsurprising." ${ }^{11}$ These are linked to a core practice of sovereign power: territorializing practices. Soguk has argued elsewhere that:

... sovereignty claims, connected inescapably to some understandings of space/territory/identity [citizen/nation/state], are 
territorializing practices in the quest for constructing 'representable' essences, meanings, identities and cultures. ${ }^{12}$

By invoking the notion of "territorializing practices," Soguk reminds us of something raised in Deleuze and Guattari's $A$ Thousand Plateaus: that is, the extent to which the migrant or refugee is not truly "deterritorialized"; only the nomad is in such a condition, par excellence. ${ }^{13}$ This is relevant to the extent that it reminds us that while the refugee certainly highlights the "originary fiction of modern sovereignty" stressing the fragility of borders, bounded identities, and the doctrine of modern sovereignty itself, the very core of what can be referred to as "refugee politics" is the very act of "reterritorialization" that makes the refugee, the forced migrant, the trafficked person, a temporal/temporary condition. Herein lies the paradox, where the refugee is at once both the representation of sovereignty's limits and a target of sovereign power. Or, as Peter Nyers has argued in a similar context: "The refugee is thus at once the purest expression of humanity, and also its constitutive limit."14

Considering Soguk's "paradox of the representable refugee," and its ability to highlight the dual character of the refugee, as both subject of resistance and product of statecraft, takes us some distance in considering to what extent refugee politics are recast in a post-September 11 context. However, while it is important to highlight this dual character of the refugee in world politics, there is still more to say. In pursuing how we might begin to (re)think and make authoritative claims about contemporary refugee politics, I argue it is necessary to introduce an account of modern politics sensitive to the diffusion of power and the centrality of "the politics of the body," so fundamental to contemporary refugee politics. To this end, I examine briefly what Michel Foucault's discussions of governmentality and biopolitics can offer.

\subsection{Biopolitics}

For millennia, man remained what he was for Aristotle: a living animal with the additional capacity for a political existence; modern man is an animal whose politics places his existence as a living being in question.

Michel Foucault ${ }^{15}$

According to Michel Foucault, "biopolitics" is about the intervention and regulatory controls of populations. ${ }^{16}$ Foucault argues that "diverse techniques for achieving the subjugation of bodies and the control of populations" marks the beginning of an era of "bio-power." ${ }^{17}$ Bio-power introduces a critical element of Foucault's "governmentality": the relation between security, territory, and population. ${ }^{18}$ Bio- power serves to politicize what Giorgio Agamben refers to as "bare life," making biological existence political. ${ }^{19}$ As the passage above poignantly states, biopolitics is a specifically modern form of politics where the biological existence of humanity is politicized, and the veil between the public and private is pushed aside. The administration or "governmentality" of the management of life through (bio)technologies of health care, education, housing, passports, etc., places various "spaces of existence" into the realm of the sovereign's power. As Foucault clearly demonstrates in his genealogy of the prison, the modern technique of punishment employs "disciplinary power" or techniques of coercion in order to train or correct "the body," which is in dramatic contrast to previous approaches that involved the ritualistic marking of the body through terror and torture. ${ }^{20}$ In summary, biopolitics marks the modern move from the sovereign power over death, to the sovereign power over life, which is bio-power. This has very important administrative and "governmental" implications.

The move from sovereign power over death to sovereign power over life involves the increased regulatory and corrective mechanisms of the state that exert forms of "disciplinary power" in order to maintain power over life bio-power. This rearticulation of sovereign power, or what Agamben refers to as the transformation of sovereign power from "territorial state to state of population," 21 is not, by and large, acknowledged by international relations theory. For the most part, international relations continues to read/represent sovereign power as the power over death; the capability of killing in order to go on living. ${ }^{22}$ Hence capital punishment could not be maintained except by invoking less enormity of the crime itself than the monstrosity of the criminal, his incorrigibility, and the safeguard of society. One had the right to kill those who represented a kind of biological danger to others. ${ }^{23}$

Foucault suggests that state-sponsored killing must be articulated on biological grounds lest it contradict the sovereign power over the maintenance of life. Here, the merits of drawing on biopolitical knowledges to conceptualize "refugee politics" is clearer. Rather than reading the subjectivity/activity of the refugee through international relations, where one is primarily drawn into debates about the maintenance of (or threats to) territorial understandings of sovereign power, biopolitical knowledge politicizes both the actions of the refugees themselves, and the (seemingly mundane) administrative procedures of the state directed at them. The (re)presentation (demonization) of the refugee as a sick body, terrorist, threat to identity, etc., plays out in the governmentality of the state vis-à-vis complex border controls that differentiate on the basis of race, class, economic need, "well-founded fears," ${ }^{24}$ health, and a host of 
other (arguably arbitrary) categories between the legitimate and the illegitimate, the banal asylum seeker, and the terrorist, the disease carrier, the job thief.

\section{3. “Camps with En-suites”: UK Refugee Biopolitics}

... we need to send out a signal to the world that we are neither open to abuse, nor a 'Fortress Britain'... It is possible to square the circle. It is a 'two-way street' requiring commitment and action from the host community, asylum seekers, and long term migrants alike.

David Blunkett MP, Foreword, Secure Borders, Safe Haven: Integration with Diversity in Modern Britain, February 2002

With its en-suite facilities and comfortable dining room, the 62-bedroom Coniston Hotel has been a favourite Sittingbourne venue for receptions and functions. Now angry residents claim that it will become a 'doss house'.

The Times, January 20, 2003

The immigrants to be dumped in Sittingbourne would have had no health checks for diseases such as tuberculosis or Aids or other contagious diseases. They could be war criminals or paedophiles and Tony Blair wouldn't care as long as they live in your street and not his.

British National Party (BNP) Leaflet distributed in Sittingbourne, January 2003

The passages above provide certain "representations" of contemporary refugee politics in the UK. The title of the 2002 White Paper produced by the government hints at the "paradoxical" nature of contemporary refugee politics: Secure Borders, Safe Haven. In the foreword, the Home Secretary, David Blunkett, stresses the importance of processing/accepting asylum seekers with a "well-founded fear," providing clear channels/chunnels ${ }^{25}$ for those economic migrants who "wish to work and contribute to the UK," while maintaining a robust system for rapidly processing bogus claimants and tackling international human trafficking. Certainly these are admirable goals, most of which were later put down in the Nationality, Immigration and Asylum Bill. The increased preoccupation with domestic security after September 11 is absent from the White Paper and the bill itself. However, as recent media accounts of Conservative calls to overhaul the asylum system and even pull out of the European Convention on Human Rights suggest, discourses of threat and security are not absent. ${ }^{26}$ In this section I focus on three issues/occurrences in contemporary UK refugee politics: the government's White Paper, Secure Borders, Safe Haven, February 2002; the murder of
Detective Constable Stephen Oake on January 15, 2003; and the scandal surrounding the conversion of the Coniston Hotel in Sittingbourne, Kent, into a refugee reception centre. These three issues expose the UK's attempts at "squaring the circle," to use the Home Secretary's language, when it comes to a continued commitment to globalization and the post-September 11 preoccupation with domestic security, as well as the increasing biopoliticization of refugee politics.

The White Paper, Secure Borders, Safe Haven, which came out in February 2002, led to the Nationality, Immigration and Asylum Bill 2002, intended to make necessary adjustments to the existing act from 1999, reflecting the contemporary realities in the politics of asylum. What were those realities? Most notably, the events of September 11 prompted nations to clamp down on migrants and refugees, as borders were (re)securitized. The Red Cross refugee camp at Sangatte continued to be a thorn in the side of UK officials, leading to a sizable amount of resources dedicated to issues of human trafficking and the problem of so-called "asylum shopping" in Europe. ${ }^{27}$ The seeming complacency of French officials when it came to the "porous" nature of Sangatte raised questions about the efficacy of the Dublin Convention $^{28}$ and was one of the contemporary issues preoccupying UK refugee politics. What is also clear from Secure Borders, Safe Haven is the centrality of the paradox between a commitment to globalization and domestic security. Under the subheading "The Challenge of Globalization," the White Paper mentions the increased interconnectedness and interdependence in the world, and the need to further liberalize movement, which was under negotiation in the WTO. ${ }^{29}$ The material ability to move and the economic necessity for service delivery is acknowledged, as, interestingly, is the idea that the line between the international and the domestic is increasingly problematic: "Globalization also means that issues previously considered 'domestic' are now increasingly international." 30 Taking account of the unique position within the EU but not part of Schengen, as well as the rather complex paradox between globalization and domestic security, the UK White Paper is a reasonable characterization of refugee politics after September 11. Of course, there is still the question of how the state deals with these new imperatives, of which the answer can also be found in Secure Borders, Safe Haven: biopolitics.

In a section entitled "Biometric Registration," the White Paper introduces a series of measures and mechanisms intended to both "detect and deter clandestine entrants," as well as increase the speed and management of legitimate migrants. ${ }^{31}$ These measures are carried out by employing "biometrics technology." These technologies of control are there to "discipline" movement and expose human traffick- 
ing. The measures themselves are based on a number of technologically advanced scanners:

$\mathrm{X} /$ gamma ray scanners; Heartbeat sensors... which can detect, by its movement, the heartbeat of a person concealed within a stationary vehicle; and, millimetric wave imaging equipment (tested by Eurotunnel)... which senses radiation emitted from within a vehicle. ${ }^{32}$

While these technological controls over movement might fit Foucault's suggestion that the "governmental" is about the politicization of the mundane, bureaucratic, mechanistic elements of power, this seems all but mundane. Not to mention the questions this raises about relations between body and machine, ${ }^{33}$ it highlights important steps in biopolitical security being taken by the state. Furthermore, as the White Paper points out, some of this equipment has already been tested by Eurotunnel, which is a private firm responsible for managing the Channel Tunnel rail system. If biopower is about the relationship between territory, security, and population, then the employment of biometric technologies appears to be a clear example of bio-power. Furthermore, the introduction of private actors into the equation not only indicates the diffuse nature of power in contemporary refugee politics, but it also points to another critical element of the relationship between biopolitics and the globalization-domestic security paradox: by involving private actors, neoliberal ideals of small government, privatization, efficiency, and so on are not sacrificed at the altar of domestic security. However, the scandal surrounding the conversion of the Coniston Hotel takes this contention further.

In mid to late January 2003, residents of some communities in the UK became aware of the transformation of certain hotels and large estate homes into so-called "induction centres." These centres are intended to house asylum seekers for their first two weeks in the UK as their claims are processed. While public opinion was rather robustly against the government move to acquire local hotels and wedding reception facilities in order to house undesirables, it was not completely because of the act itself or the kind of xenophobic fervour whipped up by far-right groups such as the British National Party (BNP). What seemed, at least in some media accounts, to be the most enraging to residents was the fact that the government had taken such steps without community consultation. As one headline proclaimed, "'Back Door' Refugee Centres Anger Residents," and here "back door" can be read to have a double meaning, as both the "back door" approach the government took in placing these centres into communities, as well as such seemingly insecure facilities acting as "back doors" for asy- lum seekers to slip into the community. I raise this episode here for a number of reasons.

First, the government's decision to acquire private facilities, run by private actors referred to as "accommodation specialists," 35 is one way of coping with the paradoxical commitments to neoliberal globalization and domestic security. Here, the state transfers authority to private actors, maintaining small government, privatization, and efficiency. In material terms, this move also released the government from the spatial restrictions of where to place induction and reception centres, therefore enabling it to further its commitment to the dispersal of asylum seekers beyond the southeast of England. Another important consideration in the hotel incident is the public reaction. While the loss of certain amenities to the community, as seemed to be the case with the Coniston Hotel in Sittingbourne, undoubtedly drew criticism, issues of security and privatization of asylum politics were equally troubling.

It is important to note that the episode regarding the conversion of hotels and estate homes into induction centres came less than one week after the murder of Detective Constable Stephen Oake. On January 15, 2003, as part of an anti-terrorist operation in Manchester, Detective Constable Stephen Oake was killed by an Algerian asylum applicant, and as the two articles appearing side by side in The Times newspaper the following morning indicate, there was no attempt to distance the issues of terrorism, a police killing, and asylum. ${ }^{36}$ If anything, for obvious reasons this incident increased the links between the terrorist threat and the politics of asylum. I raise this here, because it was in this context that the Coniston Hotel incident was first reported, which not only raised suspicions of asylum seekers being in small communities, but also the ability of a private company to take on what appeared increasingly to be an issue of high security. Oddly enough, it seemed even the Consiton's owner was misled into thinking that the hotel would be transformed into a four-star facility, and only learned the real purpose when contacted by a local newspaper. ${ }^{37}$ So what do the White Paper, the Coniston incident, and the murder of DC Stephen Oake tell us about the contemporary politics of asylum in the UK?

It is clear that the events of September 11, 2001 have worsened the situation for refugees. As the UK situation demonstrates, while other issues such as the Sangatte camp and the desire to disperse asylum seekers away from the southeast of England have been factors in changing contemporary refugee politics, negotiating the paradox between globalization and domestic security and the increasing (perceived) link, particularly after the death of DC Stephen Oake, between terrorism and the politics of asylum further complicates matters. Secure Borders, Safe 
Haven is a clear indicator of a move towards the "biopoliticization of refugee politics." The increasing dependence on private actors and the heightened role of "biometric technology" speaks to the diffuse networks of power within refugee politics and the politicization of the natural body of the refugee. As a threat in terms of disease and terrorism, or as merely a heartbeat or a radiation emission, the refugee becomes an object of scientific regulation and discipline. As the "political subjectivity" of the refugee is of little interest to the state, whether as a member of a diasporic community or a symbol of cultural diversity, the refugee is little more than a biological being that requires management and discipline, either to regiment its existence within, or prevent its entrance altogether.

\section{Conclusions: Considering Conditions of Possibility}

At the heart of this reflection on contemporary refugee politics is the question: how can we think, imagine, and make authoritative claims about contemporary refugee politics? In order to explore the struggle for the rights and political voice of refugees, it is important to examine how refugee politics are conceptualized and what might allow us to rethink it. While Nevzat Soguk's concept of the "paradox of the representable refugee" suggests that paradox is nothing new to refugee politics, it does appear that one of the central elements of post-September 11 refugee politics is a paradox between states' commitment to globalization and domestic security. Certainly one important consideration is the extent to which drawing clean lines between what is domestic and international is increasingly problematic; the central paradox and indeed the very character of refugee politics itself indicates such differentiations are problematic. However, if we are interested in the plight of refugees, the condition of speechlessness they find themselves in, and the extent to which they are subject to a proliferation of controls and disciplines, we must come to terms with the contemporary condition of refugee politics.

In this paper, I have argued that contemporary refugee politics are characterized by a core paradox, between states' commitment to globalization and powerful discourses of threat leading to preoccupations with domestic security. In negotiating this paradox, and coming to terms with the unique pressures of post-September 11 world politics, the UK White Paper, Secure Borders, Safe Haven suggests that, at least in part, a biopolitical approach was pursued. Secure Borders, Safe Haven clearly indicates the UK government's awareness of the paradox between a commitment to globalization and domestic security, and the extent to which this is also indicative of the increasingly untenable distinction between domestic and international, global and local. Furthermore, this document also indicates the centrality of biopolitics in the contemporary politics of asylum, where the subjectivity of the refugee, or perhaps more aptly put in Soguk's language, the representation or articulation of the refugee, is as little more than a heartbeat or a radiation output. The violent death of Stephen Oake indicates that links between asylum and terrorism are not wholly unfounded, and as the Coniston Hotel episode suggests, these links - real or otherwise - are not lost on the population. And while the hotel incident suggests there is public concern over the state's decision to transfer refugee politics - now steeped in discourses and representations of threat and security - to private actors, the extent to which private firms are readily seizing such responsibilities is also troubling; troubling to the extent that the interests of these actors are unclear, and the ability to draw such actors into the negotiation of refugees' struggle for rights and political voice is questionable at best.

As a reflection on contemporary refugee politics, this paper has attempted to draw out a number of core issues that have altered and challenged the struggle for refugee rights and a political voice. The increasing links, real and otherwise, with the politics of asylum and the politics of the war on terrorism have added complexity and impediments in the way of refugee advocates. In the struggle to resolve paradoxical commitments to the aims of neoliberal globalization and the (alleged) necessities of domestic security, contemporary anti-terrorist legislation in most western states seems to have chosen economic interests at the cost of civil liberties. In an attempt to cope with this complex and paradoxical terrain, states have further entrenched a biopolitics of asylum and refugee politics, where the role of private actors increases, and the biological body of the refugee becomes the political object/subject. In order to even begin to consider how movements and interests can struggle towards the protection, rights, and voice of refugees, the shifted terrain characterized by paradox, diffuse power, biopolitics, and the breakdown of many of the differentiations integral to international relations' account of world politics, and subsequently the conditions of (im)possibility for refugee politics, must be acknowledged. A sensitivity towards the globalization-domestic security paradox, and an account of politics aware of the role of bio-power and the (instrumental) politicization of the biological body of refugees, is a crucial step towards coming to terms with how to (re)think contemporary refugee politics, thus illuminating the shifted terrain upon which the struggle for refugees' protection, rights, and voice is fought.

\section{Notes}

1. Gilles Deleuze and Felix Guattari, A Thousand Plateaus: Capitalism and Schizophrenia, trans. Brian Massumi (Minneapolis: University of Minnesota Press, 1987). 
2. For a recent critical examination of the renaissance of Samue Huntington's "Clash of Civilization" thesis, see Mark B. Salter, Barbarians and Civilization in International Relations (London: Polity Press, 2002).

3. See Peter Andreas and Thomas J. Biersteker, eds., The Rebordering of North America (New York: Routledge, 2003).

4. The Conservative Party stance on asylum is a policy area where the party finds itself dangerously close to the xenophobic British National Party. The Conservative leader has argued that the notion of presumed innocence should no longer be considered when it comes to asylum seekers, suggesting that they all be placed in secure facilities upon arrival during such time as required to process them. The Conservatives have also drawn on the increasing prevalence of security discourses in their arguments about asylum. See Anne Perkins, "Terrorists Posing as Refugees, Say Tories," The Guardian, 29 January 2003.

5. The theme of Gulliver was introduced in international relations by Rob Walker in Inside/Outside: International Relations as Political Theory (Cambridge: Cambridge University Press, 1993), 125-40. The basic assumption is that we are unable to conceptualize the political beyond state sovereignty, but only account for changes in scale. We might conceive of bigger or smaller political organizations, but other than differences of scale, they are reproductions of the same sovereign organization.

6. Nevzat Soguk, "Transnational/Transborder Bodies: Resistance, Accommodation, and Exile in Refugee and Migrant Movements on the US-Mexican Border," in Challenging Boundaries: Global Flows, Territorial Identities, ed. Michael J. Shapiro and Hayward R. Alker (Minneapolis: University of Minnesota Press, 1996), 294.

7. Also see Nevzat Soguk, States and Strangers: Refugees and Displacements of Statecraft (Minneapolis: University of Minnesota Press, 1999), 15.

8. Giorgio Agamben, Homo Sacer: Sovereign Power and Bare Life (Stanford: Stanford University Press, 1999), 131.

9. Michael Dillon, "The Scandal of the Refugee: Some Reflections on the 'Inter' of International Relations and Continental Thought," in Moral Spaces: Rethinking Ethics and World Politics, ed. David Campbell and Michael J. Shapiro (Minneapolis: University of Minnesota Press, 1999), 114.

10. Soguk, States and Strangers, 9. For a provocative examination of the issue of the "speechless" condition of refugees, see Peter Nyers, "Body Politics in Motion: Refugees and States of/in Emergency” (Ph.D. dissertation, York University, 2002). Engin Isin's Being Political: Genealogies of Citizenship (Minneapolis: University of Minnesota Press, 2002) has raised related points. Indicating the extent to which the refugee is indeed a "political being," Isin argues that the strategies and technologies employed to define citizenship are equally integral to the definition of the others, the beggars, the refugees, and, as such, these figures are "being political," or for the purposes here, "political beings." Isin points out: "The closure theories that define citizenship as a space of privilege for the few that excludes others neglect a subtle but important aspect of citi- zenship: that it requires the constitution of these others to become possible", 4.

11. Soguk, States and Strangers, 18.

12. Soguk, "Transnational/Transborder Bodies," 287.

13. Deleuze and Guattari, 381.

14. Nyers, 149.

15. Michel Foucault in The Foucault Reader, ed. Paul Rabinow (New York: Pantheon Books, 1984), 265.

16. Ibid., 262.

17. Ibid.

18. Michel Foucault, "Governmentality," in The Foucault Effect: Studies in Governmentality, ed. Graham Burchell, Colin Gordon, and Peter Miller (Chicago: University of Chicago Press, 1991), 102.

19. See Agamben, Homo Sacer.

20. Michel Foucault, Discipline and Punish: The Birth of the Prison (New York: Vintage Books, 1995), 130-31.

21. Agamben, Homo Sacer, 3.

22. Michel Foucault, "Right of Death and Power over Life," in The Foucault Reader, ed. Paul Rabinow (New York: Pantheon Books, 1984), 260.

23. Ibid., 261.

24. "Well-founded fear" can be found in the Refugee Convention 1951. Also, see Philip G. Schrag, A Well-Founded Fear: The Congressional Battle to Save Political Asylum in America (London: Routledge, 2000).

25. A small play on words here is worth noting. One of the core elements of the politics of asylum in the UK over the past two to three years has centred around the Red Cross Centre at Sangatte, France. According to UK officials (and the firm responsible for running the train through the Channel Tunnel "Eurotunnel"), Sangatte was a launching point for asylum seekers to make nightly forays through the Chunnel in order to seek asylum in the UK. Over a relatively long period of time, the UK government made demands that Sangatte be closed, which finally happened late in 2002 following intensive bilateral negotiation between the UK and France. However, as some have argued, and as real numbers indicate (67,000 asylum claimants came through Sangatte in three years, while the UK total for the same period was 220,000), Sangatte may not deserve such infamy. See Richard Woods, David Cracknell, and Lauren Quaintance, "Asylum Seekers Are Still at the Gates," The Sunday Times, 8 December 2002.

26. Melissa Kite and Richard Ford, "Tougher Curbs Urged for Asylum-Seekers," The Times, 16 January 2003.

27. Re: Sangatte, see note 25.

28. Dublin Convention (September 1997) stipulates that the claims of asylum seekers should only be examined once in the $\mathrm{EU}$, and that the member state responsible for the presence of the asylum seeker is responsible for the examination.

29. Secure Borders, Safe Haven: Integration with Diversity in Modern Britain (Home Office, February 2002), 23.

30. Ibid., 25.

31. Ibid., 95 .

32. Ibid., 96. 
33. See Donna Haraway, Simians, Cyborgs, and Women: The Reinvention of Nature (London: Free Association Books, 1991).

34. Lewis Smith, "Back Door Refugee Centres Anger Residents," The Times, 20 January 2003.

35. Ibid. According to Smith's article, the two private firms employed by the government, Accommodata and The Angel Group, are regularly consulted by the government, and both have yearly turnovers in the tens of millions of pounds.

36. Ian Cobain and Russell Jenkins, "Struggle Ended as Suspect Lashed Out with Knife," The Times, 16 January 2003; Melissa Kite and Richard Ford, "Tougher Curbs Urged for AsylumSeekers," The Times, 16 January 2003.

37. Gabriel Rozenberg and Alan Hamilton, "Don't Expect a Welcome Reception at Asylum Hotel," The Times, 20 January 2003.

Benjamin J. Muller is a Ph.D. candidate in the School of Politics and International Studies, Queen's University, Belfast, and currently is teaching in the Department of Political Science, University of Victoria, Canada.

(C) Benjamin Muller, 2004. This open-access work is licensed under a Creative Commons Attribution-NonCommercial 4.0 International License, which permits use, reproduction and distribution in any medium for non-commercial purposes, provided the original author(s) are credited and the original publication in Refuge: Canada's Journal on Refugees is cited. 